\title{
Exploring Involvement Expectations for Culturally and Linguistically Diverse Parents: What We Need to Know in Teacher Education
}

\author{
Sandra M. Gonzales \\ Wayne State University \\ U. S. A. \\ Susan L. Gabel \\ Wayne State University \\ U. S. A.
}

\begin{abstract}
In the United States parental involvement is an important part of a child's education, and teachers often rely on parents to boost student achievement. This qualitative analysis employs a two-step process, first examining the data with regards to parental involvement and then using critical theories in education to examine the intersections between parental involvement findings and subtractive schooling practices in order to highlight how educational praxis, teacher perspectives, and school climate impact both parental involvement and school achievement for culturally and linguistically diverse (CLD) students.
\end{abstract}

KEYWORDS: parental Involvement, multicultural education, subtractive schooling, bilingual learners, teacher education

Preparing Teachers to Respond to Growing Demographic Shifts in the Classroom Parental Involvement Research

How Subtractive Schooling Practices Harm Student Outcomes and Parent Partnerships Concluding Thoughts and Future Directions

References

Author Contact

In the United States, parent involvement in a child's education is important. However, engaging parents as participants can be a challenging goal. Teachers with little exposure to culturally and linguistically diverse (CLD) student populations may articulate pedagogical practices borne from their own culture's experience of school and schooling and from their beliefs about children and parents in their own cultural milieu. Pedagogical strategies are often applied unilaterally with the assumption that all students were the same and the lack of understanding that the significant cultural and linguistic differences may exist and these differences impact parental involvement and student academic success (Garza \& Crawford, 
2005; Lee \& Oxelson, 2006; Sheets, 2005; Valdés 1996; Valenzuela, 2010; Walker, Shafer, \& Liams, 2004).

Teachers may not understand that their CLD students need the cultural capital to succeed in the dominant culture. Instead helping the students, the teachers may place on parents and students the burden of acquiring such capital, resulting in the application of additional pressure on them to assimilate. In this article, we argue that the burden of acquiring cultural capital be shifted to, or at least shared by, educational institutions because the data suggest that educators are largely underprepared to work effectively with CLD student and families in their school.

To explore further, we employ a two-step qualitative analysis process to examine the intricacies of parental involvement. While the findings are not exhaustive, they clearly indicate that we have much more to learn about CLD families and the various ways that their involvement impacts their children's success (Bower \& Griffin, 2011; De Carvalho, 2000; DeGaetano, 2006; Lee \& Bowen, 2006; Souto-Manning \& Swick, 2006; Sui-Chu \& Willms, 1996; Valdés, 1996).

Next, we use critical theories in education to examine the intersections of parental involvement perspectives with subtractive schooling practices. We do this to highlight how educational practice and school climate impact both parental involvement and school achievement, a gap in the literature that this article seeks to address.

\section{Preparing Teachers to Respond to Growing Demographic Shifts in the Classroom}

In an article published by the Brookings Institute, Frey (2010) gives voice to what he calls a "cultural generation gap," noting that racial demographics in the United States are quickly shifting. Frey describes how, in many other Southwestern states including Arizona, the population of children and young adults of color exceeds that of White Baby Boomers (65 + population). Frey posits that, as a nation, there is need to prepare for these demographic changes at the federal and local levels in order to promote greater equality. Moll, Santo-Santiago, and Schwartz (2013) also point to the "cultural generation gap," noting how educational institutions in particular should take note of the changing demographics in schools.

This illuminates a need for urban teachers to prepare for the growing demographic shifts in their classroom, particularly the increase of CLD students and English language learners (ELLs) in urban centers. To do so, teacher education programs must prepare educators to make culturally and linguistically responsive decisions about assessment, instruction, and instructional materials, as well as special education and ESL referrals. According to Gay (2010), Lee and Oxelson (2006), Sheets (2005), and Walker et al. (2004), culturally responsive teaching makes multiculturalism and culture the centering point for all instructional 
practice in an effort to correct subtractive schooling paradigms. The term "subtractive schooling" was coined by Valenzuela (2010) to describe how wellintentioned schools subtract resources from CLD youth through the use of assimilationist policies and practices. These policies and practices undermine learning by divesting students of their cultural and linguistic knowledge sets. When teachers miss/dismiss culturally different understandings of education or ban a student's language or cultural displays from the classroom, it works against student adjustment and academic success while also eroding a love for school that continues to decrease over time (Sheets, 2005; Valenzuela, 2010).

Rather than evaluating the appropriateness of their own pedagogical practices, teachers may instead assign blame to the parents, thinking that they are not doing their part to help their child succeed (Bower \& Griffin, 2011; SoutoManning \& Swick, 2006). To begin thinking about parental involvement and its relationship to student success, urban teachers need to understand the meaning of parental involvement and various factors associated with parental involvement whether at school or at home.

\section{Parental Involvement Research}

Parental involvement has long been held as beneficial for student development and academic achievement, and numerous studies have found a relationship between parent involvement and student educational outcomes (e.g., Bauch \& Goldring, 1995; Epstein, 1988; Jeynes, 2003, 2005, 2007; Keith, Keith, Troutman, \& Bickley, 1993; Mau, 1997; Muller, 1998; Sheldon \& Epstein, 2005; Sanders, 1998; Villas-Boas, 1998). More recent studies have sought to understand the relationship between these two factors (De Carvalho, 2000; Galindo \& Sheldon, 2012; Ice \& Hoover-Dempsey, 2011; Lee \& Bowen, 2006), particularly within the special education community (Duchnowski et al., 2012; Hosp \& Reschly, 2004; McDonnall, Cavenaugh, \& Giesen, 2012; Wagner, Newman, Cameto, Javitz, \& Valdes, 2012) and minoritized student populations (Bower \& Griffin, 2011; De Carvalho, 2000; Jeynes, 2003, 2005, 2007; Lee \& Bowen, 2006; Souto-Manning \& Swick, 2006; Sui-Chu \& Willms, 1996).

However, assessing the impact of parent involvement is fraught with complexity. For example, some research suggests that grades and test scores are less affected by parental involvement while student academic behaviors, such as motivation, persistence, and self-efficacy, are more affected (Hoover-Dempsey \& Sandler, 1995; Hoover-Dempsey, Walker, \& Sandler, 2005). Results can fluctuate depending on race and ethnicity, socio-economic status, cultural beliefs, level of acculturation, definition of involvement, and even the location of the study such as in the home or at school, as noted in the following sections. 


\section{The Difficulty of Defining Parental Involvement}

Studies vary in their definition of parental involvement. Empirical studies tend to focus on parents' investment of resources such as time, energy, and intellectual or monetary capital used to support a child's education, as well as their leveraging of social or professional networks on behalf of the school (Epstein, 1995; Fishman \& Nickerson, 2015; Grolnick \& Slowiaczek, 1994; Hayes, 2012; Ice \& Hoover-Dempsey, 2011; Sheldon \& Epstein, 2005). Parent involvement could also entail a wide variety of arrangements such as parent attendance at school events, orientations, open houses, and parent-teacher meetings, volunteering of time in class or during field trips, offering opinions, suggesting goals, fundraising for parent or student organizations as well as for classroom or school projects, and facilitating outcomes and initiating supports such as homework help (Epstein, 1988; 1995; Bower \& Griffin, 2011; Grolnick \& Slowiaczek, 1994, Sheldon \& Epstein 2005; Sui-Chu \& Willms, 1996). These investments would likely be recognized by school staff as parental involvement because they are observable and because they fit the traditional definitions adopted by many educators and educational policy-makers.

There are, however, other forms of parental involvement that are less visible and not well understood or defined (Bower \& Griffin, 2011; De Carvalho, 2000; Lee \& Bowen, 2006; Soto-Manning \& Swick, 2006; Sui-Chu \& Willms, 1996). For example, some data suggest that CLD parents, lower socio-economic status (SES) parents and parents with less education tend to be less involved in school than White parents, parents with higher SES status, and parents with more educated (Artiles et al., 2010; Duchnowski et al., 2012; Epstein, 1995; Fantuzzo, Tighe, \& Childs, 2000; Grolnick \& Slowiaczek, 1994; Harry, 2002; Hosp \& Reschly, 2004; Rodriguez, Fishman, \& Nickerson, 2015; Wagner et al., 2012; Zhang \& Bennett, 2003). Childcare and other barriers can prohibit CLD parents from participating in the same ways as White parents, yet studies indicate they do participate. Indeed, CLD parental involvement may go unnoticed because it occurs in the home and surpasses traditional involvement practices such as homework help (Bower \& Griffin, 2011). In one study by Geenen, Powers, and Lopez-Vasquez (2001), CLD parents of special education students were perceived by teachers as less involved because their involvement patterns were not visible and fell outside of traditional definitions. Examples provided were talking about life after high school and cultural teachings about values and beliefs. In another study, Souto-Manning and Swick (2006) noted how Latino/a elders passed on their knowledge to the younger generations through the sharing of stories and oral history. Other parent involvement activities they described included time spent with loved ones at church as well as the teachings that occurred during religious holidays and cultural festivities or park and museum visits, in addition to involvement with extended family members such as grandparents and others in their community (SoutoManning \& Swick, 2006). Though these same parents were perceived as less involved, they were actually more involved and expressed higher levels of 
academic caring than their White counterparts. In a study of 24,599 middle schoolers, African American parents were also found to have higher involvement than Whites in all areas except at school (Sui-Chu \& Willms, 1996). These and other studies have led researchers to believe that teachers have a limited understanding of the diverse ways in which CLD parents contribute to their child's educational success (Bower \& Griffin, 2011; De Carvalho, 2000; Lee \& Bowen, 2006; Souto-Manning \& Swick, 2006; Sui-Chu \& Willms, 1996; Valdés, 1996). Unfortunately, parental involvement strategies and expectations for parent-home partnerships are traditionally defined as a single academic construct (parents do this and achievement will go up) when in reality CLD parental involvement practices are complex and multidimensional in nature (Sui-Chu \& Willms, 1996). This complexity is explored in the following sections.

\section{Barriers to Parental Involvement}

Indeed, schools may over-rely on parents when research shows that there are many other factors impacting educational outcomes, such as parent and student status factors like race, gender and socio-economic status (Galindo \& Sheldon, 2012; Hayes, 2012; Newman, 2005; Wagner et al., 2012). Social class differences (Kozleski et al., 2008; Lai \& Vadeboncoeur, 2012; Lawson, 2003) and cultural differences in values and beliefs can create tensions between parents and schools (Chen \& Garcia, 2011; DeGaetano, 2007; Harry, 2002; Kalyanpur \& Harry, 1997; Kozleski et al., 2008; Lai \& Vadeboncoeur, 2012; Lim \& Renshaw, 2001; Zhang \& Bennett, 2003). Differences in student outcomes can also be attributed to structural barriers confronting CLD parents such as employment, transportation, or child-care (Hayes, 2012).

Other studies note a wide range of school and teacher factors impacting parent involvement (Delpit, 1995; Gay, 2002, 2010; Nieto, 2010; Sheets, 2005; Valdés, 1996; Valenzuela, 2010; Walqui, 2000). A teacher's deficit view of parents can create barriers to parental involvement (Chu \& Garcia, 2014; Kozleski et al., 2008; Lai \& Vadeboncoeur, 2012; Lightfoot, 2004; Pollack, 2012; Ravindran \& Myers, 2012; Zhang \& Bennett, 2003). Negative attitudes exhibited by school staff can also leave CLD parents feeling alienated from school due to mistrust of the system (Brandon et al., 2010; DeGaetano, 2007; Dunst, 2002; Kozleski et al., 2008; Lightfoot, 2004).

Furthermore, many parents have difficulty communicating with school personnel due to language differences (Chu \& Garcia, 2014; Torres-Burgo et al., 2010; Trainor, 2010; Zhang \& Bennett, 2003). Language differences can impact the readability of education documents and school correspondence, which can be challenging for CLD parents, especially those with limited English proficiency, placing a burden on parents that has implications for due process (Geenen et al., 2001; Mandic et al., 2012). In one study, Torres-Burgo, Reyes-Watson, and Brusca-Vega (2010) report how Hispanic parents had difficulty understanding the IEP and its procedures, which resulted in Hispanic parents communicating with the 
special education teacher less often than the non-Hispanic parents in the study and, consequently, being offered less advice about how to help their child.

\section{The Impact of Cultural and Other Differences on Teacher Perceptions of Parental Involvement}

The cultural values and beliefs of CLD parents can differ widely from the values and beliefs typically held by schools, which can lead to misunderstandings, mistrust, and tense relationships between parents and teachers (Delpit, 1995; Nieto, 2010; Sheets, 2005; Spring 2012; Valdés, 1996; Valdés, 2001; Valenzuela, 2010; Wildcat, 2001). In a study by Garcia, Perez, and Ortiz (2000), the cultural interpretations of typical child development stood in contrast to the perspective of teachers and school psychologists. In their study, Mexican American participants perceived what school officials called "delayed language development" as "typical" or "normal." Thus, they did not respond to concerns about limited verbal skills, limited use of nonverbal gestures, or inability to communicate. Instead of realizing that families have their own cultural ways of understanding language development, their lack of concern was perceived by teachers as denial or resistance to labeling.

In addition, school staff and parents may hold differing and even conflicting expectations about parent involvement that can be the result of cultural, linguistic, socio-economic, and other differences (Anderson \& Minke, 2007; Duchnowski et al., 2012; Fishman \& Nickerson, 2015; Harry, 2008; Ice \& Hoover-Dempsey 2011; Lawson, 2003; Whitaker \& Hoover-Dempsey, 2013). For example, the parent involvement mandate with regards to the IEP has historically expected parents to be advocates for their children, yet advocacy is a uniquely U.S. expectation that requires the knowledge and skills of White, middle class values about equity and parent roles (Harry, 2002; Kalyanpur, Harry, \& Skrtic, 2000; Lai \& Vadeboncoeur, 2012). When educational institutions are limited in their understanding of parental involvement, it may leave CLD families "subordinated to the rules and procedures of institutionalized practice" (Kozleski et al., 2008, p. 27). Parental advocacy requires interpersonal skills that depend on shared ways of talking about things, such as who speaks, when they speak, and whose ideas are considered most valid, which can be difficult to ascertain for CLD parents (Kozleski et al., 2008; Lai \& Vadeboncoeur, 2012).

The kinds of advocacy that schools expect depend on common definitions of home-school partnerships and access to educational information and resources that are designed for parents from a variety of educational backgrounds and literacy levels. Advocacy also depends on material properly translated into a language the parents understand (Trainor, 2010), and access to translators is critical yet often limited or insufficient (Lo, 2009) despite the fact that the U.S. Department of Education requires schools to provide translators and appropriately translated documents, a violation of which could result in a Title VI Civil Rights complaint. Some CLD parents may yield their expertise to educators as is the 
custom in their country (Garcia, Perez, \& Ortiz, 2000; Harry, 2008), which can conflict with U.S. institutional understandings of parents as advocates.

\section{Parental Involvement and Cultural Capital Theory}

According to Lee and Bowen (2006) and McNeal (1999), the kind of involvement teachers favored was highly significant among affluent European American families but less so for low-income African American, Latina/o, Asian American, or single parent families. It was theorized that the cultural capital that affluent Euro-American families were able to leverage towards achievement became magnified with home-school involvement. Lee and Bowen (2006) contend that when parents come from the same social system as the institution with which they are interacting, their economic and cultural capital automatically leads to the procurement of additional capital such that the information and resources gleaned from parent teacher conferences, assemblies, or parent-to-parent networks, have an increased capacity to influence their children's success.

On the other hand, when families with less economic and cultural capital do not come from the same social system and when their knowledge and processes lie at the periphery of such systems, their ability to impact student achievement is reduced in comparison (Lee \& Bowen, 2006). Thus, the parental involvement activities that teachers favor and that benefit Euro-American students may not have the same breadth of impact on CLD students and families. However, what did impact CLD achievement was parent expectations and aspirations for their children, as these were linked to student persistence factors (Lee \& Bowen, 2006). Nonetheless, teachers and educators are cautioned against attributing blame to CLD parents or displacing responsibility from the school to the family for underactualized student outcomes (Souto-Manning \& Swick, 2006).

Just as teachers may lack critical information about CLD parents and diverse representations of parental involvement, they may also lack the training needed to work effectively with CLD students. Teachers are often ill-equipped and indeed undereducated in the cultural forms of capital that families bring to school. Thus, teachers underutilize a significant cultural resource that could support academic and linguistic growth. Even worse, they may deem these forms of knowledge as deficits that stand in the way of educational success (Lee \& Oxelson, 2006; Moll et al., 2013; Valdés, 1996; Valenzuela, 2010). Since the largest number of CLD students are English Learners (EL) or students for whom English is a second language (ESL), this can add an additional layer of responsibility and challenge for underprepared teachers (Sullivan, 2011). In the next section, we examine how misinformation, negative attitudes, and unrealistic expectations with regards to CLD students who are ELs can harm student outcomes and parent partnerships. 


\section{How Subtractive Schooling Practices Harm Student Outcomes and Parent Partnerships}

Many teachers assume that they know the needs of EL students and ways to prepare them for success based on what they feel are common-sense strategies, making a statement like, "Teachers don't need specialized ESL training; common sense and good intentions work fine" (Walker et al., 2004, p. 145). This "common sense" analogy also leads teachers to over-refer EL students to special education because, as one teacher reported, "Special Ed to me means access to resource room and aides and these kids definitely need that" (Walker et al., 2004, p. 146). The reoccurrence of these perspectives exemplifies a lack of understanding of the needs of CLD students as well as the purpose of special education services (Walker et al., 2004).

A review of the literature suggests that teachers inappropriately utilize special education services because schools lack staff who are trained in ESL/bilingual education and most teachers are not ESL/Bilingual education endorsed, so they are not familiar with second language acquisition methods (Calderón, Slavin, \& Sánchez, 2011; Lee \& Oxelson, 2006; Lucas, Villegas, \& Freedson-Gonzalez, 2008). Many studies demonstrate that educators without such training often have deficit perspectives of EL students and do not recognize how their educational policies, school praxis, and classroom practices can be subtractive in nature (Lee \& Oxelson, 2006; Walker et al., 2004).

Valenzuela (2010) describes how subtractive schooling methods progressively subtract critical academic skills and resources that could be transferred from the home language and culture into their new learning environment. Creating a classroom environment that builds on the cultural knowledge that students bring to school could yield greater academic confidence and success (Lee \& Oxelson, 2006; Sheets, 2005; Valenzuela, 2010). On the other hand, a rigid environment that favors reduced cultural and linguistic displays can be stigmatizing and deculturalizing (Sheets, 2005; Spring, 2012; Valdés, 1996, 2001; Valenzuela, 2010). Reduced linguistic displays includes asking students and parents to speak only English or denying students the ability to codeswitch between languages, which limits their capacity to convey subject matter knowledge (Pollard, 2002). Over time, such environments become subtractive in that they subtract a love of learning from students and can lead to poor academic outcomes and school dropout (Valenzuela, 2010).

Furthermore, educators are unaware of curricular mismatches in terms of literature, lectures, and assignments. When, for example, EL students underperform on tasks that require greater linguistic variation and competency, it can be mistaken for a learning disability (Sullivan, 2011). According to Sullivan (2011, p.320), other triggers for special education might rely on "poorly designed language assessments (MacSwan \& Rolstad, 2006), and weak psychoeducational assessment practices (Figueroa \& Newsome, 2006)." In addition, 
ineffective instruction can negatively influence assessment outcomes, especially when coupled with the fact that tests are designed for native English speakers and thus may not be reliable or valid for ELs.

Many educators struggle to set up a culturally responsive classroom and may feel like it is not their job to assist CLD students (Lee \& Oxelson, 2006; Walker et al., 2004; Valdés, 2001). In two separate studies of teacher attitudes towards English Learners (Lee \& Oxelson, 2006; Walker et al., 2004), teachers in both studies expressed that it was not possible to reach all students given their limited time and resources and thus felt that they should teach to the majority of their students. They thereby abdicated their role to the ESL teacher since, according to them, it was the ESL teacher's job to teach ESL students, suggesting that the mainstream teacher should only teach mainstream students. In addition, teachers in both studies were found to have ethnocentric bias, which led to negative attitudes and beliefs about EL students and their parents. These negative attitudes can deepen the divide between CLD parents and schools.

Levine and Lezotte (2001), Walker et al. (2004), and Wrigley (2000) noted how negative attitudes among school principals influenced teacher perceptions of EL students and families by blaming ELs for their own academic struggles and constructing a school climate that transmits and perpetuates bias. In one example, Walker et al., (2004) recount how a principal gathered all the ESL students in a room and said:

"You are not allowed to speak anything but English." The principal's edict was enforced by school staff. In the cafeteria, the same supervisor and a janitor began to regularly deny students the right to a federally-funded free breakfast if they caught them speaking their native language while in line to receive their food (p. 144).

Withholding food and services for speaking one's primary language is a form of structural violence that can humiliate students, leading to social isolation, a lowered self-esteem, and a reduced sense of belonging that can harm student adjustment and academic outcomes and make family-school alliances tense (Lee \& Oxelson, 2006; Sheets, 2005; Valdés, 2001; Valenzuela, 2010; Walker et al., 2004).

These tensions can increase when teachers and administrators refuse to allow students to speak their native language at school and pressure EL parents to speak only English to their students at home, which is symptomatic of how teachers and administrators do not always know what is best for CLD students and subsequently respond in ways that undermine learning. Lee and Oxelson (2006) cite a long list of benefits to bilingualism that are under-actualized by school personnel, when they report:

Proficiency in the heritage language not only facilitates English acquisition....and leads to higher academic achievement ...but also results in greater cognitive flexibility including an enhanced ability to deal with abstract concepts.... (pp. 454-455) 
Many teachers do not realize how asking parents to speak only English stunts language development in both English and their child's home language, as parents are often ill-equipped to provide the linguistic support students need in what is for them a language and culture they too might struggle to understand (Lee \& Oxelson, 2006).

Furthermore, according to Cummins (2008), educators often conflate the differences between Basic Interpersonal Communication Skills (BICS) and Cognitive Academic Language Proficiency (CALP) and mistakenly exit students who speak conversational English from EL resources after just one or two years. Sullivan (2011) notes that prematurely exiting ELs and isolating them from important resources has led to special education referrals later on, particularly in $5^{\text {th }}$ grade and beyond where such referrals are noted to increase.

This happens because school staff and teachers who lack ESL and bilingual education training often confuse conversational English or playground English (BICS) with academic English or the kind of English proficiency needed to be successful in the classroom (CALP) (Cummins, 2008; Gibbons, 1991). Cummins (2008) utilizes an example to distinguish the difference between playground language and classroom language. Classroom language would call for a student needing to communicate something like: "if we increase the angle by 5 degrees, we could cut the circumference into equal parts." Classroom language requires the use of "higher order thinking skills, such as hypothesizing, evaluating, inferring, generalizing, predicting or classifying" (Cummins, 2008, p. 75 , as originally cited in Gibbons, 1991). This kind of language is more complex than playground language. Nonetheless, many teachers hear students speaking English and see growth on language assessments, and so they mistakenly assume that they are ready to exit and no longer need services.

Walker et al. (2004) and Reeves (2006) recount how teachers unrealistically expected students to be language proficient in one or two years. In actuality, EL students need five to seven years to develop the kind of classroom/academic language ability necessary for success in school (Cummins, 2008; Reeves, 2006). When teachers incorrectly conclude that playground English is the same as higherorder classroom language acquisition, they curtail a child's linguistic potential and jeopardize long-term academic success (Cummins, 2008; Gee, 1990; Gibbons, 1991).

Nevertheless, this confusion is not uncommon and reiterates the fact that teachers and administrators without proper training often operate without accurate information and are more likely to make uninformed decisions with regards to EL students. Even more concerning is that these behaviors-if left unchecked-can lead to inappropriate referrals for special education services. Sullivan (2011) explains that ELs, in particular, are over-represented in special education and even more so if they attend schools with undertrained staff and few support services.

Sullivan (2011) reports that the lack of proper training and knowledge among educational professional is also manifested in the opposite tendency among some teachers who under-refer their EL students to special education 
services. This occurs, according to Sullivan, because many teachers are unable to distinguish between learning disabilities and the natural process of secondlanguage acquisition. For example, the curriculum (e.g., literature, lectures, assignments), instructional practices, and norms for behavior can position CLD students as underperforming on tasks that require greater linguistic variation and competency, which leads teachers to suspect a learning disability (Sullivan, 2011). Other triggers for special education referrals might rely on "poorly designed language assessments, and weak psycho-educational assessment practices" (Sullivan, 2011, p. 320). In addition, ineffective instruction can negatively influence assessment outcomes, coupled with the fact that tests are designed for native English speakers and thus may not be reliable or valid for EL's.

\section{Concluding Thoughts and Future Directions}

Based on the extant literature on CLD students and parents, a conclusion could be made that more study needs to be done on the current rapid demographic changes in the classroom and the lack of training among educators to properly address the growing number and needs of the EL students they serve. If educators are underprepared and undertrained, then their ability to competently assess and address student needs is in question. This may also mean that parents are being misled and provided with misinformation from an institution they are encouraged to trust. The misrepresentation of their student's academic ability and needs may jeopardize the parent's ability to appropriately advocate on behalf of their child, which may lead to increased parent-blaming and deficit-thinking on the part of the school (Souto-Manning \& Swick, 2006). When this happens, the current cycle is left unchallenged and both the student and parent are left stigmatized.

As a result, we contend that schools are inadequately prepared to respond to the growing demographic shifts in CLD students and families. Teachers and staff across the spectrum are under-trained and schools are under-resourced, leading to deficit assumptions, mismatched assessment tools, inappropriate referrals to special education, and what could be by and large considered subtractive schooling practices (Lee \& Oxelson, 2006; Sheets, 2005; Valenzuela, 2010; Walker et al., 2004). Subtractive practices negatively impact both CLD students and parents in the same stigmatizing ways by fostering a compensatory perspective that undermines family strengths while marginalizing the very knowledge constructs that could aid school success.

CLD parents are often scapegoated for student underachievement and accused of not caring about their children's education when they do not display the same kinds of involvement behaviors as their White counterparts (Bower \& Griffin, 2011; Souto-Manning \& Swick, 2006; Sui-Chu \& Willms, 1996). Research shows that there are many structural barriers to CLD parental involvement such as child care, work responsibilities, lack of appropriately translated documents, lack of resources, unwelcoming school environment, and subtractive schooling practices, that can better explain CLD parental involvement patterns. 
Institutional re-tooling is needed on a large scale. Such re-tooling should address the structural and pedagogical issues that impede CLD student success while also attending to a more holistic understanding of school and family partnership. At the highest level, re-tooling should disrupt subtractive power dynamics. De Carvalho (2000) critiques the traditional parent involvement paradigm, suggesting that CLD parents are subordinated to the roles assigned by educational policy-makers who perpetuate the idea that school and education are synonymous, that the home is an extension of the school, and that the family is an instrument of the school's curricular goals. Under this model, forms of education outside of the domain of educational policy become invisible. Thus the diverse educative practices of CLD parents do not enjoy the same equity as those elicited by White and higher SES families (De Carvalho, 2000).

To shift this paradigm, one suggestion is to seek out counternarratives that enhance institutional ways of knowing by examining parental involvement from the perspective of the family as opposed to the institution (Gonzales, 2009; Leichter, 1979). One such example is the work of Hope Jensen Leichter and her colleagues, who, in the late 1960s, began a body of research that ran through the 1980s, seeking to understand kinship networks and the ways in which they were used by families and communities to educate (Leichter, 1974, 1979; Leichter \& HamidBuglione, 1983; Leichter \& Mitchell, 1978; Leichter, Mitchell, Rogers, \& Leib, 1967).

The word "kinship" comes from traditional Native American family networks where both blood relatives and non-blood community members, including those who were adopted into a tribe and those who joined or married into the community, were all considered "kin" or "family" (Sachs, 2011). It was a more inclusive model than the nuclear family model in that it ensured that all people in a community were taken care of and given support to and received support from their members (Sachs, 2011). In the African American (Hines \& Boyd-Franklin, 2005) and Latina/o community, these kinship networks function much like those in Native American communities (Sachs, 2011). In the Latino/a community these networks have been called "familismo" (Niemeyer, Westerhaus, \& Wong, 2009; Piña-Watson, Ojeda, Castellon, \& Dornhecker, 2013; Sabogal, Marín, Otero-Sabrogal, Marín, \& PérezStable, 1987; Smith-Morris, Morales-Campos, Alvarez, \& Turner, 2012).

To better understand how kinship networks were used by families, Leichter and her colleagues spent time in CLD homes, talking with and observing families and extended family networks. Cognitive processes as well as social and institutional exchanges were examined to understand how families deployed their resources in ways that supported their children's education. Their research found that kinship networks that included grandparents, aunts, uncles, and cousins were often undermined by a system designed to reinforce a nuclear family model that was limited in scope because it focused mostly on parents. Grandparents, who have status in many CLD systems and who help maintain family traditions while also helping children to re-shape themselves in new ways that compliment both their home and school culture, were often perceived by schools as a barrier that 
holds the family from moving forward into the contemporary (Gonzales, 2014; Leichter, 1974).

Indeed a CLD child's deep connections to extended family networks, sense of family loyalty, and willingness to make sacrifices on behalf of the family, such as helping with childcare, eldercare, and/or working, are often cited as deficits by schools because it is thought that these loyalties concurrently promote poor attendance and school dropout (Calzada, Tamis-LeMonda, \& Yoshikawa (2013). However, Calzada, Tamis-LeMonda, and Yoshikawa (2013) note how kinship networks, such as familismo in the Latino/a community, can also serve as a source of strength, support, and inspiration for a young person, contributing to "lower rates of substance use...lower rates of behavior problems... and better psychological adjustment..." (p. 1698). These same scholars, in addition to Sachs (2011) and Hines \& Boyd-Franklin (2005), also posit that extended family networks may serve as a protective shield against the many obstacles and stressors related to poverty, acculturation, and discrimination in Native American, Latina/o, and African American communities.

Institutional re-tooling should include an expanded understanding of educational involvement patterns in CLD families as well as an expanded definition of "family" (Souto-Manning \& Swick, 2006). Unfortunately, over time and as a result of colonialism, the concept of family has become so narrow and un-inclusive that many CLD families must function within a system, in this case an educational system, that often contradicts their own values, creating a form of cognitive dissonance (Sachs, 2011, Souto-Manning, \& Swick, 2006). Such is the case when schools and school teachers emphasize the nuclear family model of "parental involvement" where roles are limited as opposed to the more inclusive extended family model that incorporates whole "family involvement" as defined by each individual family (Souto-Manning \& Swick, 2006). Whole family involvement might include teachers, support staff, and administrators. These are not just professionals who work for a district but rather important members of each child's extended family constellation, all engaged in teaching and learning together for the betterment of the community, which ultimately benefits the child. This also ensures that teachers and families, districts and schools, all share equally in the responsibility of increasing cultural capital and leveraging resources in ways that benefit the entire group, the entire classroom, the entire district.

This level of re-tooling requires that educators exercise intercultural communication skills to work with students and families one on one as well as across cultures, skills that help them explore the visible as well as invisible ways of knowing by seeking out information and resources, thought-partnering, and engaging CLD students and their families in ways that are relational as opposed to transactional (Brown, 2004; Gay, 2010; Sheets, 2005; Valenzuela, 2010). Classroom skills associated with student educational outcomes include teacher familiarity with student linguistic and cultural displays and frames of reference (Calderón et al., 2011; Crawford, 2004; Cummins, 2008; Lee \& Oxelson, 2006; Sheets, 2005; Walker et al., 2004). Critically needed for teachers are also the ability to establish culturally safe classroom environments (Sheets, 2005; Brown 
2004) and familiarity with culturally responsive teaching practices and classroom management techniques as well as the selection and implementation of culturally relevant curricula (Brown, 2004; Gay, 2010, 2002; Sheets, 2005).

Lastly, institutional re-tooling should be structural, taking place at the leadership level, with the goal of moving school policies and practices beyond a compensatory and impediment-based praxis towards culturally responsive schools. Such schools are characterized by culturally responsive teachers, classrooms, literature, assessments, and curricula, where meaning-making is shared and occurs in ways that are multilingual, multimodal, diverse, and dynamic. Such schools are spaces that invite families and extended family constellations to share their skills, their experiences, and their stories to provide counternarratives that inform, indeed transform, institutional perspectives and leverage the rich cultural capital of CLD families and communities.

\section{References}

Anderson, K. J., \& Minke, K. M. (2007). Parent involvement in education: Toward an understanding of parents' decision making. The Journal of Educational Research, 100(5), 311-323.

Artiles, A. J., Kozleski, E. B., \& Trent, S. C. (2010). Justifying and explaining disproportionality, 1968-2008: A critique of underlying views of culture. Exceptional Children, 76(3), 279-299.

Bauch, P. A., \& Goldring, E. B. (1995). Parent involvement and school responsiveness: Facilitating the home-school connection in schools of choice. Educational Evaluation and Policy, 17, 1-21.

Bower, H., \& Griffin, D. (2011). Can the Epstein model of parental involvement work in a high-minority, high-poverty elementary school? A case study. Professional School Counseling, 15(2), 77-87.

Brandon, R. R., Higgins, K., Pierce, T., Tandy, R., \& Sileo, N. (2010). An exploration of the alienation experienced by African American parents from their children's educational environment. Remedial and Special Education, 31(3), 208-222.

Brown, D. F. (2004). Urban teachers' professed classroom management strategies: Reflections of culturally responsive teaching. Urban Education, 39(3), 266-289.

Calderón, M., Slavin, R., \& Sánchez, M. (2011). Effective instruction for English learners. The Future of Children, 21(1), 103-127.

Calzada E. J., Tamis-LeMonda, C. S., \& Yoshikawa, H. (2013). Familismo in Mexican and Dominican families from low-income, urban communities. Journal of Family Issues, 34(2), 1696-1724. 
Chen, W. B., \& Garcia, A. (2011). Parental involvement in the prereferral process: Implications for schools. Remedial and Special Education, 32(6), 447-457.

Chu, S. Y., \& Garcia, S. (2014). Culturally responsive teaching efficacy beliefs of in-service special education teachers. Remedial and Special Education, 35(4), 218-232.

Crawford, J. (2004). Educating English learners: Language diversity in the classroom. Los Angeles, CA: Bilingual Education Serv.

Cummins, J. (2008). BICS and CALP: Empirical and theoretical status of the distinction. In B. V. Street \& N. Hornberger (Eds), Encyclopedia of language education, $2^{\text {nd }}$ Edition, Volume 2: Literacy (pp. 71-83). New York, NY: Springer.

De Carvalho, M. E. (2000). Rethinking family-school relations: A critique of parental involvement in schooling. New York, NY: Routledge.

DeGaetano, Y. (2007). The role of culture in engaging Latino parents' involvement in school. Urban Education, 42(2), 145-162.

Delpit, L. (1995). Other people's children: Cultural conflict in the classroom. New York, NY: The New Press.

Duchnowski, A. J., Kutash, K., Green, A. L., Ferron, J. M., Wagner, M., \& Vengrofski, B. (2012). Parent support services for families of children with emotional disturbances served in elementary school special education settings: Examination of data from the Special Education Elementary Longitudinal Study. Journal of Disability Policy Studies, 24(1), 36-52.

Dunst, J. (2002). Family-centered practices: Birth through high school. The Journal of Special Education, 36(3), 141-149.

Epstein, J. L. (1995). School/family/community partnerships. Phi Delta Kappan, 76(9), 701-712. Retrieved from http://search.proquest.com.proxy.lib.wayne. edu/docview/218509027? accountid=14925

Epstein, J. L. (1988). Homework practices, achievements, and behaviors of elementary school students (Report No. 26). Washington, DC: Office of Educational Research and Improvement (ED).

Fantuzzo, J., Tighe, E., \& Childs, S. (2000). Family involvement questionnaire: A multivariate assessment of family participation in early childhood education. Journal of Educational Psychology, 92(2), 367-376.

Figueroa, R. A., \& Newsome, P. (2006). The diagnosis of LD in English learners: Is it nondiscriminatory? Journal of Learning Disabilities, 39(3), 206-214.

Fishman, C. E., \& Nickerson, A. B. (2015). Motivations for involvement: A preliminary investigation of parents of students with disabilities. Journal of Child and Family Studies, 24, 523-535.

Frey, W. (2010). Baby boomers and the new demographics of America's seniors. Generations, 34(3), 28-37. 
Galindo, C., \& Sheldon, S. B. (2012). School and home connections and children's kindergarten achievement gains: The mediating role of family involvement. Early Childhood Research Quarterly, 27, 90-103.

Garcia, S. B., Perez, A. M., \& Ortiz, A. A. (2000). Mexican American mothers' beliefs about disabilities: Implications for early childhood intervention. Remedial and Special Education, 21(2), 90-100.

Garza, A. V., \& Crawford, L. (2005). Hegemonic multiculturalism: English immersion, ideology, and subtractive schooling. Bilingual Research Journal, 29(3), 599-619.

Gay, G. (2002). Preparing for culturally responsive teaching. Journal of Teacher Education. 53(2), 106-116.

Gay, G. (2010). Culturally responsive teaching: Theory, research, and practice. New York, NY: Teachers College Press.

Gee, J.P. (1990). Social linguistics and literacies: Ideologies in discourses. New York, NY: Falmer Press.

Geenen, S., Powers, L. E., \& Lopez-Vasquez, A. (2001). Multicultural aspects of parent involvement in transition planning. Exceptional Children, 67(2), 265282.

Gibbons, P. (1991). Learning to learn in a second language. Portsmouth, NH: Heinemann.

Gonzales, S. M. (2009). Learning that I belong: Establishing a link between Midwestern Chicanos and Mesoamerican communities (Doctoral dissertation), Teachers College, Columbia University. Retrieved from http://gradworks.umi.com/33/48/3348352.html

Gonzales, S. M. (2014). Abuelita epistemologies: Counteracting subtractive schools in American education. Journal of Latinos in Education, 14(1), 4054.

Grolnick, W. S., \& Slowiaczek, M. L. (1994). Parents' involvement in children's schooling: A multidimensional conceptualization and motivational model. Child Development, 65(1), 237-252.

Harry, B. (2002). Trends and issues in serving culturally diverse families of children with disabilities. The Journal of Special Education, 36(3), 131-138.

Harry, B. (2008). Collaboration with culturally and linguistically diverse families: Ideal versus reality. Exceptional Children, 74(3), 372-388.

Hayes, D. (2012). Parental involvement and achievement outcomes in African American adolescents. Journal of Comparative Family Studies, 43, 567582. 
Hines, P. M., \& Boyd-Franklin, N. (2005). African American families. In M. McGoldrick, J. Giordano \& N. Garcia-Preto (Eds.), Ethnicity and family therapy, (pp. 87-100). New York, NY: The Guilford Press.

Hoover-Dempsey, K. V., \& Sandler, H. M. (1995). Parental involvement in children's education: Does it make a difference? Teachers College Record, 97(2), 313-331.

Hoover-Dempsey, K. V., Walker, J. M., \& Sandler, H. M. (2005). Why do parents become involved? Research findings and implications. The Elementary School Journal, 106(2), 105-130.

Hosp, J. L., \& Reschly, D. J. (2004). Disproportionate representation of minority students in special education: Academic, demographic, and economic predictors. Exceptional Children, 70(2), 185-199.

Ice, C. L., \& Hoover-Dempsey, K. V. (2011). Linking parental motivations for involvement and student proximal achievement outcomes in homeschooling and public schooling settings. Education and Urban Society, 43(3), 339-369.

Jeynes, W. H. (2007). The relationship between parental involvement and urban secondary school student academic achievement: A meta-analysis. Urban Education, 42(1), 82-110.

Jeynes, W. H. (2005). A meta-analysis of the relation of parental involvement to urban elementary school student academic achievement. Urban Education, 40(3), 237-269.

Jeynes, W. H. (2003). A meta-analysis: The effects of parental involvement on minority children's academic achievement. Urban Education, 35(2), 202218.

Kalyanpur, M., \& Harry, B. (1997). A posture of cultural reciprocity: A practical approach to collaboration between professionals and parents of culturally diverse background. Journal of Child and Family Studies, 6(4), 487-509.

Kalyanpur, M., Harry, B., \& Skrtic, T. (2000). Equity and advocacy expectations of culturally diverse families' participation in special education. International Journal of Disability, Development and Education, 27(2), 119-136.

Keith, T. Z., Keith, P. B., Troutman, G. C., \& Bickley, P. G. (1993). Does parental involvement affect eighth-grade student achievement? Structural analysis of national data. School Psychology Review, 22(3), 474-496.

Kozleski, E. B., Engelbrecht, P., Hess, R., Swart, E., Eloff, I., Oswald, M., Molina, A., \& Jain, S. (2008). Where differences matter: A cross-cultural analysis of family voice in special education. The Journal of Special Education, 42(1), 26-35.

Lai, Y., \& Vadeboncoeur, J. A. (2012). The discourse of parent involvement in special education: A critical analysis linking policy documents to the experiences of mothers. Educational Policy, 27(6), 867-897. 
Lawson, M. A. (2003). Parent and teacher perceptions of parent involvement. Urban Education, 38(1), 77-133.

Lee, J. S., \& Bowen, N. K. (2006). Parent involvement, cultural capital, and the achievement gap among elementary school children. American Educational Research Journal, 43(2), 193-218.

Lee, J. S., \& Oxelson, E. (2006). "It's not my job": K-12 teacher attitudes toward students' heritage language maintenance. Bilingual Research Journal, 30(2), 453-477.

Leichter, H. J. (1979). Families and communities as educators. New York, NY: Teachers College Press.

Leichter, H. J. (1974). The family as educator. New York, NY: Teachers College Press.

Leichter, H. J., \& Hamid-Buglione, V. (1983). An examination of cognitive processes in everyday family life. New York, NY: Columbia University.

Leichter, H. J., \& Mitchell, W. E. (1978). Kinship and casework: Family networks and social intervention. New York, NY: Teachers College Press.

Leichter, H. J., Mitchell, W. E., Rogers, C., \& Lieb, J. (1967). Kinship and casework. New York, NY: Russell Sage Foundation.

Levine, D., \& Lezotte, L. (2001). Effective schools research. In J. Banks \& C. Banks (Eds.), Handbook of research on multicultural education (pp. 525-547). San Francisco, CA: Jossey-Bass.

Lightfoot, D. (2004). "Some parents just don't care": Decoding the meanings of parental involvement in urban schools. Urban Education, 39(1), 91-107.

Lim, L., \& Renshaw, P. (2001). The relevance of sociocultural theory to culturally diverse partnerships and communities. Journal of Child and Family Studies, 10(1), 9-21.

Lo, L. (2009). Collaborating with Chinese families of children with hearing impairments. Communication Disorders Quarterly, 30(2), 97-102.

Lucas, T., Villegas, A. M., \& Freedson-Gonzalez, M. (2008). Linguistically responsive teacher education preparing classroom teachers to teach English language learners. Journal of Teacher Education, 59(4), 361-373.

Mandic, C. G., Rudd, R., Hehir, T., \& Acevedo-Garcia, D. (2012). Readability of special education procedural safeguards. The Journal of Special Education, 45(4), 195-203.

McDonnall, M. C., Cavenaugh, B. S., \& Giesen, J. M. (2012). The relationship between parental involvement and mathematics achievement for students with visual impairments. The Journal of Special Education, 45(4), 204-215. 
McNeal, R. B. (1999). Parental involvement as social capital: Differential effectiveness on science achievement, truancy, and dropping out. Social Forces, 78, 117-144.

MacSwan, J., \& Rolstad, K. (2006). How language proficiency tests mislead us about ability: Implications for English language learner placement in special education. Teachers College Record, 108(11), 2304-2328.

Mau, W. (1997). Parental influences on the high school student's academic achievement: A comparison of Asian immigrants, Asian Americans, and White Americans. Psychology in the Schools, 34(3), 267-277.

Moll, L. C., Soto- Santiago, S. L., \& Schwartz, L. (2013). Funds of knowledge in changing communities. In K. Hall, T. Cremin, B. Comber, \& L. C. Moll (Eds.), International handbook of research on children's literacy, learning, and culture (pp. 172-183). Somerset, NJ: Wiley and Sons.

Muller, C. (1998). Gender differences in parental involvement and adolescents' mathematics achievement. Sociology of Education, 71(4), 336-356.

National Center for Educational Statistics (2015). Fast facts: English language learners. Washington, DC: Institute of Educational Sciences. Retrieved from https://nces.ed.gov/fastfacts/display.asp?id=96

Newman, L. (2005). Family involvement in the educational development of youth with disabilities: A special topic report from the National Longitudinal Transition Study-2 (NLTS-2). Menlo Park, CA: SRI International.

Niemeyer, A. E., Westerhaus, K. J., \& Wong, M. M. (2009). Parental involvement, familismo, and academic performance in Hispanic and Caucasian adolescents. North American Journal of Psychology, 11(3), 613-631.

Nieto, S. (2010). The light in their eyes: Creating multicultural learning communities. New York, NY: Teachers College Press.

Nieto, S. (2009). Language, culture, and teaching: Critical perspectives. New York, NY: Routledge.

Piña-Watson, B., Ojeda, L., Castellón, N. E., \& Dornhecker, M. (2013). Familismo, ethnic identity, and bicultural stress as predictors of Mexican American adolescents' positive psychological functioning. Journal of Latina/o Psychology, 1(4), 204-217

Pollack, T. M. (2012). Unpacking everyday "teacher talk" about students and families of color: Implications for teacher and school leader development. Urban Education, 48(6), 863-894.

Pollard, S. (2002). The benefit of code switching within a bilingual education program. Honors Projects, 1-17.

Ravindran, N., \& Myers, B. J. (2012). Cultural influences on perceptions of health, illness, and disability: A review and focus on autism. Journal of Child and Family Studies, 21, 311-319. 
Reeves, J. R. (2006). Secondary teacher attitudes toward including Englishlanguage learners in mainstream classrooms. The Journal of Educational Research, 99(3), 131-143.

Rodriguez, R. J., Blatz, E. T., \& Elbaum, B. (2014). Strategies to involve families of Latino students with disabilities: When parent initiative is not enough. Intervention in School and Clinic, 29(5), 263-270.

Sabogal, F., Marín, G., Otero-Sabogal, R., Marín, B. V., \& Pérez-Stable, E. J. (1987). Hispanic familism and acculturation: What changes and what doesn't? Hispanic Journal of Behavioral Sciences, 9, 397-412.

Sachs, S. M. (2011). Remembering the traditional meaning and role of kinship in American Indian societies to overcome problems of favoritism in contemporary tribal government. Indigenous Policy Journal, 22(2), 1-12.

Sanders, M. G. (1998). The effects of school, family, and community support on the academic achievement of African American adolescents. Urban Education, 33(3), 385-409.

Sheets, R. H. (2005). Diversity pedagogy: Examining the role of culture in the teaching-learning process. Boston, MA: Pearson Allyn and Bacon.

Sheldon, S. B., \& Epstein, J. L. (2005). Involvement counts: Family and community partnerships and mathematics achievement. The Journal of Educational Research, 98(4), 196-207.

Smith-Morris, C., Morales-Campos, D., Alvarez, E. A. C., \& Turner, M. (2012). An anthropology of Familismo: On narratives and description of Mexican/Immigrants. Hispanic Journal of Behavioral Sciences, 35(1), 3560.

Souto-Manning, M., \& Swick, K. J. (2006). Teachers' beliefs about parent and family involvement: Rethinking our family involvement paradigm. Early Childhood Education Journal, 34(2), 187-193.

Spring, J. (2012). Deculturalization and the struggle for equality: A brief history of the education of dominated cultures in the United States. New York, NY: McGraw Hill.

Sui-Chu, E. H., \& Willms, J. D. (1996). Effects of parental involvement on eighthgrade achievement. Sociology of Education, 69(2), 126-141.

Sullivan, A. L. (2011). Disproportionality in special education identification and placement of English language learners. Exceptional Children, 77(3), 317334.

Torres-Burgo, N., Reyes-Watson, P., \& Brusca-Vega, R. (2010). Perceptions and needs of Hispanic and non-Hispanic parents of children receiving learning disabilities services. Bilingual Research Journal: The Journal of the National Association for Bilingual Education, 23(4), 373-387. 
Trainor, A. A. (2010). Diverse approaches to parent advocacy during special education home-school interactions: Identification and use of cultural and social capital. Remedial and Special Education, 31(1), 34-47.

Valdés, G. (1996). Con respeto: Bridging the distances between culturally diverse families and schools. New York, NY: Teachers College Press.

Valdés, G. (2001). Learning and not learning English: Latino students in American schools. New York, NY: Teachers College Press.

Valenzuela, A. (2010). Subtractive schooling: US-Mexican youth and the politics of caring. Albany, NY: Suny Press.

Villas-Boas, A. (1998). The effects of parental involvement in homework on student achievement in Portugal and Luxembourg. Childhood Education, 74(6), 367-371.

Wagner, M., Newman, L., Cameto, R., Javitz, H., \& Valdes, K. (2012). A national picture of parent and youth participation in IEP and transition planning meetings. Journal of Disability Policy Studies, 23(3), 140-155.

Walker, A., Shafer, J., \& Liams, M. (2004). "Not in my classroom": Teacher attitudes towards English language learners in the mainstream classroom. NABE Journal of Research and Practice, 2(1), 130-160.

Walqui, A. (2000). Access and engagement: Program design and instructional approaches for immigrant students in secondary school. McHenry, IL: Center for Applied Linguistics and Delta Systems Co.

Whitaker, M., \& Hoover-Dempsey, K. (2013). School influences on parents' role beliefs. The Elementary School Journal, 114(1), 73-99.

Wildcat, D. R. (2001). Indigenizing education: Playing to our strengths. In V. Deloria, Jr. \& D.R. Wildcat, Power and place: Indian education in America (pp. 7-20). Boulder, CO: Fulcrum.

Wrigley, P. (2000). The challenge of educating English language learners in rural areas. NABE News, 24(2), 10-13.

Zhang, C., \& Bennett, T. (2003). Facilitating the meaningful participation of culturally and linguistically diverse families in the IFSP and IEP process. Focus on Autism and Other Developmental Disabilities, 18(1), 51-59.

\section{Author Contact}

Sandra M. Gonzales: bm6380@wayne.edu

Wayne State University, 5425 Gullen Mall - 285 Education, Detroit, MI, 48202

Susan L. Gabel: susan.gabel@wayne.edu

Wayne State University, 5425 Gullen Mall - 289 Education, Detroit, MI, 48202 